\title{
Adult Brain Stem Mixed Glioma
}

National Cancer Institute

\section{Source}

National Cancer Institute. Adult Brain Stem Mixed Glioma. NCI Thesaurus. Code C9371.

A mixed glioma of the brain stem that occurs during adulthood. 